\title{
Two New Species of the Genus Philoponella (Araneae: Uloboridae) from Taiwan and Borneo
}

\author{
Hajime YosHIDA $^{11}$ \\ 吉田 哉1)：台湾およびボルネオ産ヒメウズグモ属 \\ (クモ目：ウズグモ科) の 2 新種
}

\begin{abstract}
Two new species of the spider genus Philoponella (Uloboridae) are described from Taiwan and Borneo, South East Asia, under the names, Philoponella nigromaculata (Taiwan) and P. sabah (Borneo).
\end{abstract}

In my previous papers (YoshidA, 1980, 1982a, b, 1991), I reported Taiwanese spiders of the family Uloboridae. In this paper, I wish to describe two new species of the genus Philoponella Mello-Leitão, 1917 from Taiwan and Borneo. Up to the present, only one species, Philoponella prominens (BöSENBERg et STRAND, 1906), is known from Taiwan, and there is no record of this genus from Borneo. The genus Philoponella is easily distinguished from the other uloborid genera by the male palpus with a conductor spike, the male carapace with a broad, transverse thoracic groove and the epigynum with a ventral atrium whose posterior margin is formed by two lateral lobes (OPELL, 1979). This genus is mainly distributed in tropical area of the world.

The holotypes and the allotypes of the new species described in this paper are deposited in the collection of the Arachnological Society of Japan, Otemon Gakuin University, Osaka, and the paratypes tentatively preserved in my private collection.

Before going further, I wish to express my hearty thanks to Mr. Mamoru Yoshimura for offering valuable specimens for the present study.

\section{Philoponella nigromaculata sp. nov.}

(Figs. 1-5)

Male (holotype). Total length $3.00 \mathrm{~mm}$. Carapace length $1.24 \mathrm{~mm}$, width $1.11 \mathrm{~mm}$. Abdomen length $2.05 \mathrm{~mm}$, width $0.92 \mathrm{~mm}$. Measurements of legs $(\mathrm{mm})$ as in Table 1.

Carapace oval, with a projecting region of anterior median eyes and a

1) 7-16, Kagota 2-chome, Yamagata, Yamagata, 990 Japan

于990 山形市篭田 2 丁目7番16号

Accepted December 5, 1992 
Table 1. Lengths of legs of Philoponella nigromaculata sp. nov. (ơ holotype).

\begin{tabular}{cccccc}
\hline Leg & Femur & Patella + Tibia & Metatarsus & Tarsus & Total \\
\hline I & 1.68 & 1.68 & 1.89 & 0.84 & 6.09 \\
II & 0.95 & 0.89 & 0.84 & 0.63 & 3.31 \\
III & 0.68 & 0.68 & 0.63 & 0.47 & 2.46 \\
IV & 1.11 & 1.16 & 0.95 & 0.68 & 3.90 \\
\hline
\end{tabular}

transverse thoracic groove. Diameters of anterior median eyes larger than the others $(3: 2)$. Anterior median eyes five-sixths their diameter apart and fourthirds to laterals. Posterior median eyes triple their diameters apart and twice to laterals. Lateral eyes their diameter apart. Median ocular area, anterior width: posterior width: length $=9: 10: 8$. First femur with one prolateral and one retrolateral spines. First tibia with two dorsal, five prolateral and four retrolateral spines. Palpal organ as shown in Fig. 3; conductor spike longer than the apical part of median apophysis spur; conductor with basal lobe large and tongueshaped.

Carapace brown with a pair of wide blackish lines. Chelicerae, maxillae, labium and legs light brown. Sternum light brown, dusky marginated. Abdomen grayish brown with longitudianl black lines laterally, a pair of large black spots on the posterior part and white dorsal pigments.

Female (allotype). Total length $5.53 \mathrm{~mm}$. Carapace length $1.63 \mathrm{~mm}$, width $1.47 \mathrm{~mm}$. Abdomen length $4.32 \mathrm{~mm}$, width $2.11 \mathrm{~mm}$. Measurements of legs $(\mathrm{mm})$ as in Table 2.

Table 2. Lengths of legs of Philoponella nigromaculata sp. nov. (ㅇ allotype).

\begin{tabular}{cccccc}
\hline Leg & Femur & Patella + Tibia & Metatarsus & Tarsus & Total \\
\hline I & 2.42 & 2.26 & 2.74 & 1.00 & 8.42 \\
II & 1.37 & 1.21 & 1.21 & 0.68 & 4.47 \\
III & 1.05 & 0.84 & 0.89 & 0.63 & 3.41 \\
IV & 1.89 & 1.95 & 1.58 & 1.00 & 6.42 \\
\hline
\end{tabular}

Carapace circular, with a rectangular thoracic groove. Diameters of anterior median eyes larger than the others $(8: 5)$. Anterior median eyes three-fourths their diameter apart and two-thirds to laterals. Posterior median eves 2.4 times their diameters apart and 1.6 times to laterals. Lateral eyes 1.6 times their diameters apart. Median ocular area square, First femur without spines. First tibia with short and weak spines. Calamistrum 0.4 time as long as fourth metatarsus. Epigynum as shown in Figs. 4-5.

Carapace dusky brown with wide black flecks. Legs dusky brown basally pale. First tibia distally blackish. Abdomen dusky grayish brown with dorsal white pigments, and lateral and ventral dusky flecks. In light-colored specimens, basal color light brown, and a pair of blackish spots of the abdomen distinct.

Type series. Holotype: $\sigma^{\pi}$ and allotype: 우, Nanshantsi. Nantow Cnunty. Taiwan. 30-III-1979, H. YoshidA. Paratypes: $1 \delta^{\Uparrow}, 1$ 우, 2 우 juv.. sam- data as for the holotype; 1 ๙ $^{-1} 1$ 우 3 우 juv., Penpuhtsi, Nantow County, Taiwan, 2-IV- 
1979, H. Yoshida.

Other collecting records. $1 \precsim, 1$ 우, 1 우 juv., Chihpen spring, Taitung County,
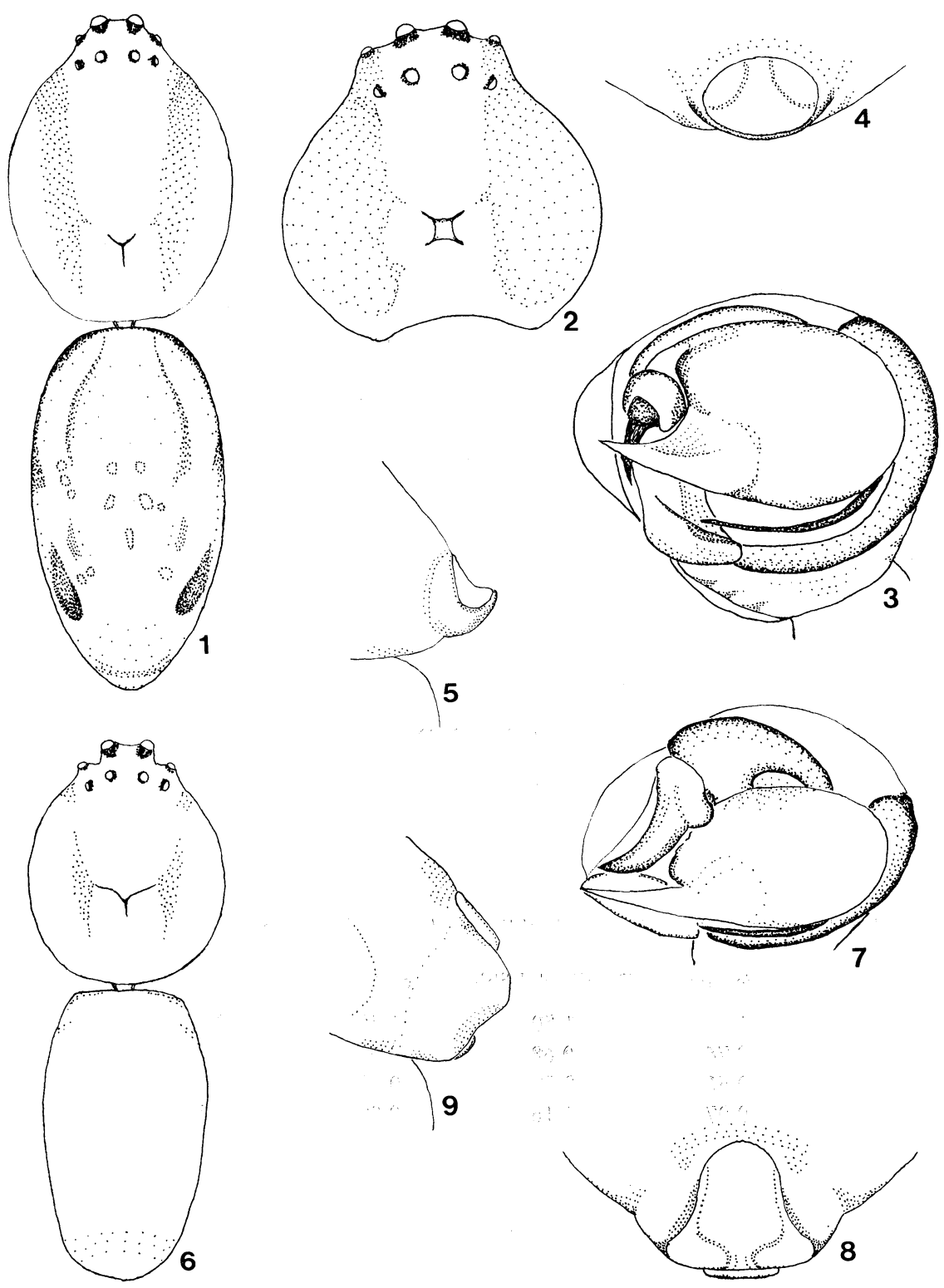

Figs. 1-9. 1-5, Philoponella nigromaculata sp. nov.; 6-9, P. sabah sp. nov.—1, 6, Male, dorsal view; 2, female carapace, dorsal view; 3, 7, male palpus, subapical view; 4, 8, epigynum, ventral view; 5, 9, epigynum, lateral view. 
Taiwan, 16-VII-1977, H. YoshIDA; 1 우 juv., Chihpeng spring, 15-VII-1977, H. Yoshida.

Distribution. Taiwan.

Ecology. At Nanshantsi, many females and males were found hanging from threads of the horizontal web of Psechrus sp., and their own webs could not be seen. The Psechrus spider seems related to $P$. sinensis BERLAND, 1914 redescribed by LEVI (1982).

Remarks. Opell (1979) revised the genera and tropical American species of the family Uloboridae, and designated three species groups of the genus Philoponella Mello-Leitão, 1917. The new species belongs to the speciesgroup of $P$. republicana (SIMON, 1891). It is related to $P$. raffrayi (Simon, 1891) described from Singapore, but distinguished from the latter by the male palpus with curved median apophysis spur and large conductor basal lobe. This new species is also allied to $P$. sabah sp. nov., but distinguished from the latter by the male carapace with short thoracic groove, the female carapace with rectangular thoracic groove, the legs without blackish flecks, the abdomen with a pair of posterior black spots and the structure of the genital organ.

$P$. prominens (BöSENBERg et STRAND, 1906) is recorded from Taiwan, and belongs to the species-group of $P$. semiplumosa (SIMoN, 1893). It is widely distributed in Japan, Korea, China and Taiwan. P. prominens may be synonymous with $P$. truncata (THORELL, 1895) described from Burma.

Etymology. The specific name is derived from the black flecks on the abdomen.

\section{Philoponella sabah sp. nov.}

(Figs. 6-9)

Male (holotype). Total length $2.63 \mathrm{~mm}$. Carapace length $1.11 \mathrm{~mm}$, width $0.97 \mathrm{~mm}$. Abdomen length $1.53 \mathrm{~mm}$, width $0.71 \mathrm{~mm}$. Measurements of legs $(\mathrm{mm})$ as in Table 3.

Table 3. Lengths of legs of Philoponella sabah sp. nov. (o holotype).

\begin{tabular}{cccccc}
\hline Leg & Femur & Patella + Tibia & Metatarsus & Tarsus & Total \\
\hline I & 1.32 & 1.50 & 1.45 & 0.63 & 4.90 \\
II & 0.74 & 0.68 & 0.61 & 0.42 & 2.45 \\
III & 0.66 & 0.53 & 0.45 & 0.37 & 2.01 \\
IV & 0.97 & 1.16 & 0.82 & 0.55 & 3.50 \\
\hline
\end{tabular}

Carapace oval, with a region of anterior median eyes projecting anteriorly and a broad, transverse thoracic groove. Diameters of anterior median eyes larger than the others $(7: 4)$. Anterior median eyes four-sevenths their diameter apart and eight-sevenths to laterals. Posterior median eyes 2.5 times their diameters apart and 1.5 times to laterals. Lateral eyes 1.5 times their diameters apart. First femur with one dorsal, one prolateral and one retrolateral spines. First tibia with one dorsal, three prolateral and four retrolateral spines. Palpal 
organ as shown in Fig. 7; median apophysis spur curved outward; conductor with basal lobe small.

Basal color light brown. Carapace with a pair of wide blackish lines. Patellae of legs with blackish flecks. Tibiae, metatarsi and tarsi distally blackish. Abdomen with distal flecks blackish.

Female (allotype). Total length $5.11 \mathrm{~mm}$. Carapace length $1.61 \mathrm{~mm}$, width $1.39 \mathrm{~mm}$. Abdomen length $3.47 \mathrm{~mm}$, width $1.58 \mathrm{~mm}$. Measurements of legs $(\mathrm{mm})$ as in Tabel 4.

Table 4. Lengths of legs of Philoponella sabah sp. nov. (우 allotype).

\begin{tabular}{cccccc}
\hline Leg & Femur & Patella + Tibia & Metatarsus & Tarsus & Total \\
\hline I & 2.37 & 2.37 & 3.16 & 1.11 & 9.01 \\
II & 1.32 & 1.32 & 1.53 & 0.79 & 4.96 \\
III & 1.21 & 1.00 & 1.00 & 0.63 & 3.84 \\
IV & 2.00 & 2.21 & 1.58 & 1.00 & 6.79 \\
\hline
\end{tabular}

Carapace suboval, without thoracic groove. Diameters of anterior median eyes larger than the others $(5: 2)$. Anterior median eyes three-fifths their diameter apart and one to laterals. Posterior median eyes triple their diameters apart and 2.5 times to laterals. Lateral eyes 1.5 times their diameters apart. Median ocular area, anterior width: posterior width: length $=10: 10: 9$. First femur without spines. First tibia with short and weak spines. Calamistrum half as long as fourth metatarsus. Epigynum as shown in Figs. 8-9; lateral lobe large.

Basal color grayish light brown. Carapace and sternum darker marginated. Each segment of legs distally dark. Abdomen with dorsal white pigments, and lateral and ventral dusky flecks.

Type series. Holotype: $ð^{\nwarrow}$, allotype: 우 and paratype: 1 우 juv., Sepilok, Sandakan, Sabah, Borneo, Malaysia, 27-VIII-1977, M. Yoshimura.

Distribution. Malaysia: Borneo (Sabah).

Remarks. This species belongs to the species-group of $P$. republicana (Simon, 1891), and is allied to $P$. raffrayi (Simon, 1891) and $P$. nigromaculata sp. nov. Discriminating characters between the new species and $P$. nigromaculata sp. nov. are given under the description of $P$. nigromaculata. This species is distinguished from $P$. raffrayi (SrMON, 1891) by the male palpus with curved median apophysis and the epigynum with large lateral lobes. Sabah.

Etymology. The specific name is a noun in apposition after the State of

\footnotetext{
摘 要

台湾およびボルネオ産のウズグモ科ヒメウズグモ属の 2 新種をPhiloponella nigromaculata (台湾) と Philoponella sabah（ボルネオ）の名のもとに記載した.
} 


\section{References}

Levi, H. W., 1982. The spider genera Psechrus and Fecenia (Araneae: Psechridae). Pac. Insects, 24: 114-138.

Opell, B. D., 1979. Revision of the genera and tropical American species of the spider family Uloboridae. Bull. Mus. comp. Zool., 148: 443-549.

Simon, E., 1891. Voyage de M. E. Simon au Venezuela. Observations biologiques sur les Arachnides. Ann. Soc. ent. France, 60: 5-14, pls. 1-4.

Thorell, T., 1895. Descriptive Catalogue of the Spiders of Burma. $406 \mathrm{pp}$. London.

YoshIDA, H., 1980. Six Japanese species of the genera Octonoba and Philoponella (Araneae: Uloboridae). Acta arachnol., 29: 57-64.

1982a. Spiders from Taiwan I. Two new species of the genus Octonoba (Araneae: Uloboridae). Ibid., 30: 71-74.

1982b. Spiders from Taiwan II. Three species of the genera Hyptiotes and Miagrammopes (Araneae: Uloboridae). Proc. Jpn. Soc. syst. Zool., (22): 18-20.

1991. A note on the Japanese genera Uloborus, Zosis, Octonoba and Philoponella (Araneae: Uloboridae). Atypus, (98/99): 21-26. (In Japanese.) 